\title{
Development of Multiprofessional Simulation-based Education in South Ostrobothnia, Finland
}

\author{
By Mari Salminen-Tuomaala*
}

\begin{abstract}
Continuous multiprofessional development and networking are essential elements of health and social care practice today. This paper gathers together the results gained so far of a regional research and development project and discusses their application and implications for future. The aims of the project were to create a network-like simulated learning environment, to develop multiprofessional simulation education for medical students and for students representing two levels of nursing education and to create a multiprofessional simulation-based coaching programme for health and social care professionals in small and medium-sized enterprises. The project partners were two educational institutions and a Central Hospital in Finland. The first sub-project involved an online survey at the turn of 2016 and 2017, whose purpose was to describe nursing and medical staff's $(n=125)$ knowledge of simulated learning and their experiences about the usefulness of simulation-based education. Quantitative data was analysed using SPSS Statistics for Windows 24 and qualitative data using inductive content analysis. Another online survey was conducted as part of the second sub-project in 2017 to study nurse and practical nurse students' experiences $(n=21)$ of joint simulation training. The results were analysed using SPSS. The third sub-project, which aims at the development of a new simulation coaching project for health and social care staff in small and medium-sized enterprises, also involved a survey conducted in 2017 to study staff's learning needs $(n=125)$. The results of the three surveys confirmed that both nursing and medical staff, students and professionals working in small and medium-sized enterprises find multiprofessional simulation-based learning effective and useful in promoting networking and the exchange of knowledge, skills and support. This paper also discusses the practical applications of the project results.
\end{abstract}

Keywords: Development, Multiprofessional collaboration, Network, Simulation-based education

\section{Introduction}

This article describes the development of multi-professional simulationbased education in South Ostrobothnia, a region with a population of 200,000 in western Finland. The work is being carried out within the framework of a research and development project for the years 2016-2020. This paper gathers together the results gained so far and discusses their application and implications for future.

The aims of the project are threefold: 1) creation of a network-like simulated learning environment; 2) development of multiprofessional simulation education for medical students and for students representing two levels of nursing education and 3) creation of a multiprofessional simulation-based coaching programme for health and social care professionals in small and medium-sized enterprises.

The regional project partners are South Ostrobothnia Hospital District, Seinäjoki University of Applied Sciences and Seinäjoki Vocational Education Centre. The Hospital District provides specialized medical services for the population of 18 municipalities in western Finland. Most of the services are

\footnotetext{
${ }^{*}$ Senior Lecturer, Seinäjoki University of Applied Sciences, Finland.
} 
concentrated in the central hospital, but some psychiatric services are available across the region. The Hospital District works in close collaboration with primary health care and social services (Etelä-Pohjanmaan Sairaanhoitopiiri 2019). The second partner, The University of Applied Sciences is a multidisciplinary institution of higher education, which currently offers 19 Bachelor and 8 Master degree programmes. The number of full-time students is 4,800. The School of Health Care and Social Work of the University offers degree programmes in nursing, public health nursing, physiotherapy, elderly care and social work (SeAMK-About us 2019).The third partner, the Vocational Education Centre, offers 23 upper secondary-level vocational qualifications in various fields of study for 4,500 students. The students of social and health care are trained to become practical nurses and emergency medical technicians. (Sedu 2019).

Based on recent research, the article first discusses multiprofessional networking, collaboration and simulation learning to provide a background for the project results. Following that, three sub-projects marked A-C are described in separate sections. Each section contains a description of the methodology, results and practical application of a sub-project. The article ends with a discussion and conclusions.

\section{Literature Review}

This article discusses the development of competence, multiprofessional collaboration and networking in health and social work education and practice, carried out using simulation-based pedagogy. Smooth collaboration between the various professionals responsible for client or patient care has been found to affect the recipients' experience of the care quality positively (Beaubien and Baker 2004). Also in a wider context, the importance of interdisciplinary and multiprofessional collaboration (combining knowledge and skills to reach common objectives) has been found to be on the increase in modern societies (Grigg et al. 2003, Holland 2006, Katajamäki 2010).

Genuine multiprofessional collaboration means that professionals with different educational backgrounds and work roles work together and develop their work based on mutual respect and appreciation (Drinka and Clark 2000). In today's society, multiprofessional collaboration can take the form of dialogue, in which participants gather knowledge and perspectives, build networks and cross borders together (Isoherranen et al. 2008). The collaboration is not possible without clear but flexible coordination and allocation of roles and responsibilities. It has also been said that multiprofessional collaboration is about participation, competence and sharing of responsibility and power in decision-making. These attributes are both the aim and prerequisites for successful collaboration (Vuokila-Oikkonen 2002).

Networks, another important concept in this article, have been compared to a series of knots linked to each other. These knots can be material or immaterial, and formal or informal structures (Castells 2000). A network can consist of individual actors working as partners seeking to reach both individual and collective 
objectives (De Man 2004, Provan and Kenis 2008). In an optimal situation, the participants have equally valuable roles as parts of the network, in which they communicate openly and complement each other (Linnamaa and Sotarauta 2000, Valkokari et al. 2008). To succeed, networking organizations should be guided by the principles of participatory action, uniform practices and open access to information. In an educational institution, for example, this would mean that both managers, teaching staff and various experts employed in the organization actively contribute to the development of the work (Karjalainen et al. 2016).

Successful networking is characterized by joint development efforts, creative solutions and agility (Kuure and Lidman 2012). It enables sharing of knowledge and competence between organizations. Committing oneself to networking entails long-term planning and allocation of resources, but networks can also result in more functional allocation of responsibilities and use of resources. In fact, a more effective use of resources can be the incentive underpinning networking activities (Ståhle and Laento 2000, Vesalainen 2002). In a wellfunctioning network, collaboration is intensive and dynamic, and the partners commonly share values and practices (Ståhle and Laento 2000). Such collaboration can help manage complex phenomena in a rapidly changing environment (Linnamaa and Sotarauta 2000).

The third essential concept in this article is simulation-based education. In simulation-based education, an effort is made to create a near-authentic learning environment and context based on the participants' aims and learning needs. The experience is immersive - learners can feel that they are part of the environment. Simulation-based learning is also action-based (Hansen and Bratt 2015) and it can help build a bridge between theory and practice. Simulation-based education can be used to develop both generic and specific competencies.

There is evidence that simulation can be effective in practicing team work, interaction and collaboration skills, as well as clinical care situations. Simulation and other action-based methods been found to suit both students and professionals participating in continuing education programmes, and they can be useful in enhancing nurse-physician collaboration and mutual appreciation (McPherson et al. 2001, Baker et al. 2006). Simulation-based learning has even been found to improve such complex skills and attributes as problem-solving, emotional intelligence and situational sensitivity (Duff 2013, Forneris et al. 2015) and it can increase participants' confidence levels (Cooper et al. 2012, March et al. 2014). All these improvements can be expected to improve care quality and patient and client (Issenberg et al. 2005, Duff 2013, Jeffries 2015, Forneris et al. 2015).

Finally, a few observations should be made from the perspective of continuous development of competence in the health and social sector. It is likely that care providers will be expected to possess an increasingly complex set of skills and knowledge in future (Holli and Saloranta 2016). This is necessary for example to respond to the needs of the older population, who will mostly likely suffer from multiple health and social problems or dysfunction (ICN 2012). In Finland, where budgets for education have become tighter, educational institutions are struggling to meet the demands placed by the new competence 
requirements in curricula and by the need to intensify collaboration with practice. In addition, the universities of applied sciences in particular have been assigned the mission of creating and developing attractive learning, research and innovation environments, which also meet the needs of professionals in practice (Ministry of Education and Culture 2014). Providers of education are expected to anticipate constantly changing client needs and to develop new practices, services and pathways of studies, while taking into account the perspective of employment policy. The work can only become possible with help of open dialogue and reciprocal sharing of knowledge and skills between education and practice (Mäkimattila 2014, Research and Innovation Council 2014). At best, this can result in building of bridges and creation of new forms of collaboration (Salminen-Tuomaala 2015, Salminen-Tuomaala and Jaskari 2017). It has been suggested that the aim should be to cross the boundaries between organizations and disciplines, not only locally, but also nationally and internationally (Järviniemi 2012).

\section{The Three Sub-projects}

This chapter describes three separately conducted sub-projects within the overall research and development project still underway (2016-2020) in South Ostrobothnia, Finland. Each section contains the methodology and results of the respective sub-projects. The more detailed survey results for each subproject have been described in earlier articles (Salminen-Tuomaala et al. 2017, Salminen-Tuomaala and Jaskari 2017, Salminen-Tuomaala et al. 2018, Salminen-Tuomaala et al. 2019 forthcoming)

Sub-project A: Hospital Staff Survey on Simulation-based Learning and Environment

Methodology

This sub-project involved an Internet-based (Webropol) survey conducted with medical and nursing staff of the regional Hospital District. The aim of the project was to gain an overview of the staff's knowledge and experiences regarding simulation-based learning and simulated environments. The underpinning idea was to gather user-oriented knowledge that could be used to develop the teaching. The questionnaire, used to collect data at the turn of the years 2016 and 2017, consisted of both quantitative and qualitative items. SPSS for Windows 24 was employed to analyse the quantitative data, and inductive content analysis was used to examine the responses to the qualitative material.

$\underline{\text { Results }}$

The results are based on a response rate of $28 \%(n=125)$. The majority of the respondents rated their knowledge of simulation as a method either moderate (women $31 \%$, men $39 \%$ ) or quite weak (women 26\%, men 34\%). Somewhat 
surprisingly, the nursing staff members, who were past 50, were more confident about their knowledge levels compared to the colleagues in their thirties $(p=.001$; Kruskall-Wallis test). It must be noted that simulation-based pedagogy had not been used at the time of the older age group's initial education.

The same observation was made as regards knowledge of simulated learning environments. Again, the older age group reported higher self-ratings $(\mathrm{p}=.001)$. The greatest group in both men $(42 \%)$ and women $(38 \%)$ found their knowledge as moderate, but there was a statistically nearly significant difference $(p=.077)$ between male and female respondents, with women rating their knowledge as higher.

It was also discovered that both doctors and nurses would appreciate simulation-based learning opportunities to practice the management of various clinical situations, that is theoretical and practical competences, communication, counselling and collaboration with other professional groups. On one hand, the respondents stressed to importance to practise acute situations, in which smooth collaboration between professionals is called for. On the other hand, they also mentioned recurring challenging situations. These can, for example, involve demanding patient or family counselling (education). According to the respondents, simulations can be used to practise teamwork and management skills and they can be helpful in looking into the roles of managers and employees. Simulation-based learning would also be an excellent way of orienting newcomers (Salminen-Tuomaala et al. 2017).

\section{Practical application of the results}

Besides providing information about what teaching contents should be included in the future simulation-based training programmes, the survey facilitated decision-making on the learning environments. It was concluded that, as far as possible, the partners should share their virtual and simulated learning environments. Using each other's concrete simulation facilities as well as virtual learning environments will create a network, which facilitates knowledge sharing and combining. Procurement of similar simulators through common bid processes can also create additional synergy among the partners. Currently the University of Applied Sciences can offer facilities for simulating scenarios typical of emergency clinics, intensive care units or common wards, whereas the Vocational Education Centre offers opportunities for practicing prehospital emergency services, including the ambulance context. The third partner, the Central Hospital, has simulation learning facilities for trauma, operating room and labour room scenarios. Future improvements involve creating a bank of actors, that is experts by experience available for roles of clients and patients.

\section{Sub-project B: Joint Simulation Training for Two Student Groups}

\section{Practical arrangements}

This sub-project is associated with the aim of the overall project to provide joint simulation education for medical students and for students that represent 
two levels of nursing education. Up until know, the training experiment has been conducted once with two different groups of nursing students representing the University of Applied Sciences and the Vocational Education Centre. The students, who are close to their graduation, specialise in acute nursing (University) and prehospital emergency care (Vocational Education Centre). Four expert lecturers, two from both educational institutions, are responsible for planning and implementing the simulation training.

The joint simulation training takes place during two days. The scenarios involve the care of trauma patients at the site of the incident, in the ambulance, at the emergency clinic and in the intensive care unit. Critical learning contents involve patient assessment using the ABCDE approach, teamwork, effective communication and medical consultation to ensure a safe care pathway.

Methodology

An online survey was conducted in 2017 to study nurse and practical nurse students' $(n=21)$ experiences of the joint simulation training. The questionnaire consisted of Likert-type items and three open questions. The results were analysed using SPSS for Windows. As there was only a limited number of short responses to the open questions, they were not analysed, but used as a support to the statistical data.

$\underline{\text { Results }}$

Both nurse and practical nurse students found the joint simulation training useful. The action-based scenarios especially facilitated their teamwork and communication skills, and increased their understanding of the rights and limitations involved in different nursing roles (Salminen-Tuomaala and Jaskari 2017).

Practical application of the results

The observation has been made that communication between different groups of nursing has become clearer. In addition, since the simulation training, students remember to repeat orally what patient medication has been administered. The next joint simulation-based learning for students will be arranged in autumn 2019. In the future, the project team is planning to involve medical students in the simulated sessions.

Sub-project C: Creation of a Multiprofessional Simulation Coaching Concept for SME Staff in Health and Social Services

\section{Project background and aims}

This sub-project involves small and medium-sized enterprises or SMEs, whose staff numbers range from a few to 250 and whose maximum net turnover remains under 50 million euro (European Commission 2014). In recent years, many local and regional actors have become increasingly aware of the challenges faced by SMEs in the health and social sector. They have great difficulty in competing with major chains and in keeping up with the new technological 
solutions, changing practices and the structural change of health and social services in Finland. Both the client population and care providers are ageing at a rapid pace, and lack of trained professionals has become a problem in many regions.

This sub-project, carried out in 2017-2019 and funded by the European Social Fund, is an attempt to respond to these concerns and to local and regional staff's practical and theoretical learning needs. The project aims at improving the quality of training by tailoring it to the specific needs of the participants. Much of the project impact relies on local and regional networking and on sharing interdisciplinary knowledge. The aim is that the coaching programme will produce permanent new practices and forms of collaboration, also between the Hospital District and the educational institutions. Improved staff competence in SMEs is likely to make the enterprises more attractive to clients and new employees. It can also increase client safety, occupational safety and, in the long run, result in better health and social services.

\section{Methodology}

This sub-project uses an instrument based on a systematic literature review and a preliminary assessment of learning needs conducted at the SMEs in spring 2017. This questionnaire, which contains both quantitative $(n=44)$ and qualitative $(n=4)$ items, was first used to assess staff learning needs in SMEs. The same instrument will be used to evaluate the effectiveness of the interventions at the end of the project.

Twenty SMEs operating in the health and social work sector (child protection, mental health, care of old people) took part in the study. The data was collected from staff members $(n=125)$ late in 2017 using Internet-based software and analysed by SPSS for Windows 23 and by inductive content analysis. The majority $(83 \%)$ of the respondents in these enterprises were women, and most of them $(90 \%)$ had a vocational qualification or a higher education degree in nursing or related area. Practical nurses formed the greatest occupational group (47\%), and $22 \%$ of the respondents worked in a managerial position.

\section{$\underline{\text { Results }}$}

The survey obtained a high response rate $(96 \%)$. Respondents reported various theoretical and practical learning needs. Some of the needs were individual, while others (multiprofessional collaboration, company development, networking) were more strongly associated with the development of the enterprise and the working community. Respondents were confident about their ability to recognise client needs and support clients' psychosocial and physical ability to function. Despite this, they reported a need to develop their interaction and client counselling skills. Other learning needs involved the management of acute situations, coping with aggressive behaviour and the use of digital tools and information technology. The more detailed results have been described in articles published recently (Salminen-Tuomaala et al. 2018, Salminen-Tuomaala et al. 2019 forthcoming). 
Practical application of the results

An innovative simulation coaching concept based on participants' needs evolved as a result of this sub-study. For the first time in Finland, social and healthcare staff of SMEs gathered together for interactive, action-based and concrete learning sessions, especially suitable for professionals with long a work history.

In practical terms, the coaching consists of workshops and collaborative full-scale simulations involving manikins, simulation video equipment and sometimes teachers (coaches) acting the part of a demanding patient or client. The coaching takes partly place in project partners' facilities, partly in the enterprises' own facilities, according to their specific needs. This means that the simulation coaches must carefully study each context and set of learning needs before planning and implementing any contents. The aim for the future is to encourage participant involvement in planning the scenarios.

The participants form a multiprofessional, interdisciplinary group, which enables benchmarking and peer mentoring or sharing knowledge and experiences. The coaches are teachers working in pairs and they may represent the same or different fields of expertise.

As an example of concrete learning needs: Within the framework of the simulation coaching, participants have an opportunity to learn to use and test new technology in their own work environment. Simulations can be used to learn general technical skills or to learn about health and welfare technologies that support clients' self-care.

\section{Discussion}

The main idea in the ongoing research and development project described in this paper is to bring together educational institutions, small and mediumsized enterprises and the central hospital under the shared goal of better collaboration, communication and new kind of education using state-of-the art simulation and ICT technology. The project aims at the exchange of knowledge and support between students, teachers and care providers and between overlapping and related disciplines.

The development of multiprofessional simulation-based education has proceeded at a brisk pace over the past few years, as a result of close collaboration between motivated individuals engaged in the development activities at the Central Hospital, the Vocational Education Centre and the University of Applied Sciences. The experiences have been positive; the joint simulation-based training sessions have been found to benefit nurse and practical nurse students, as they provide an opportunity to practise multiprofessional collaboration before graduation and to become aware of the various roles and responsibilities in nursing. The recently created network of simulated learning environments has been an economically and practically wise decision, which has increased synergy among all concerned parties by giving them an access to various environments. 
The similar manikins in these environments, for example, make it easy and safe for learners to practice in a new setting.

The possibility to practice in a simulated environment is important because many hospitals take in a smaller number of nurse and practical nurse students for clinical practice periods than in previous years. The same challenge has been mentioned in earlier research as well (Rossetti et al. 2014, Murray et al. 2008). The near-genuine simulated scenarios and concrete learning environments are a feasible alternative to clinical practice (Hravnak et al. 2007, Brown J. 2008, Brown A. 2015). Secondly, it could be said that simulation-based learning has one advantage over clinical practice; it provides an opportunity to practise ethically and socially demanding situations. The same observation has been made by Braude et al. (2015).

Finally, both participants and teachers agree that the simulation coaching concept developed for staff in SMES is an effective and useful way of learning. Motola et al. (2013) have also stressed usefulness of creating simulated scenarios based on the target organization's needs and expectations. To sum up the new, unique elements in the coaching programme: 1) planning and implementation based on SMEs' individual learning needs; participants' involvement in planning, implementation and evaluation; 2) alternating individually tailored simulation sessions in the company's facilities with joint simulation sessions for all participants in project partners' facilities; 3) coaching in the genuine company context; 4) teachers working in pairs; multiprofessional coaching given by lecturers of nursing and social work and 5) a new kind of learning experience and pathway, which starts with the learner's and company's current situation.

\section{Limitations}

In this three-fold project, the results of the first and the second sub-project can be best applied outside the context of the project. These two sub-projects had adequate sample sizes and response rates, and appropriate research approach and methods. Pre-testing of the questionnaire further improved the external validity of these sub-studies. The Internet-based software was also pre-tested and found suitable for the purpose. The results of the first sub-project can be utilised to develop multiprofessional simulation training in various healthcare organizations regionally, nationally and internationally. The third sub-project, conducted with SMEs, had a very high response rate $(96 \%)$, and the results can be generalized to similar national and international enterprises interested in simulation-based training for their staff. In contrast, the results of the second sub-project (the training experiment with nursing students), cannot be much generalized beyond this particular group due to the limited sample size and number of responses. These results can only be considered indicative of how to proceed in the further development of joint training sessions for nursing and medical students in the region described. However, the combination of the three sub-projects provides an overall picture of important themes in the development of multiprofessional simulation-based training. 


\section{Conclusion}

Multiprofessional simulation-based learning and coaching are an effective way of developing clinical competences, collaboration and networking in health and social work education and practice. Simulation-based coaching is seen to promote professional growth, because it helps the participants become aware of their personal development needs in various situations. It is also possible to develop dialogic leadership, empathy and understanding of another person through the simulation scenarios.

A well-functioning network may offer a possibility to develop professional contacts and to identify opportunities for useful partnerships. Networking is a good way to expand knowledge by taking advantage of the viewpoints and experience of others. It may help professionals to remain on top of trends and developments in health care and social work. The multiprofessional network can function as a good resource. Sharing of knowledge between professionals and organizations is useful for both the professionals and their clients. It can improve the quality of care, client safety and occupational safety.

Multiprofessional simulation-based coaching is an attractive and effective way to learn problem-solving, emotional intelligence, situational sensitivity and teamwork skills. The simulation coaching can be even seen as an excellent opportunity for benchmarking and collaborative development of new ideas and solutions. It can improve decision-making in day-to-day management tasks.

It is essential for the new simulation coaching concept that the simulation scenarios are based on the target organization's needs. The participants' involvement is useful in planning, implementation and evaluation of the simulation coaching process. The quality of training will be better when it's tailored to the specific needs of the participants and arranged in the genuine company contexts. Thus, simulation-based coaching provides an opportunity to take account to the participants' current learning needs and goals and the organization's context as a genuine environment.

Multiprofessional simulation-based coaching is an innovative learning pathway, which starts with the learner's and company's current situation. Thus, the simulation coaches, teachers, must study each organization context before planning any contents and prepare for simulation carefully. Simulation-based coaching demands a lot of situational sensitivity from the coaches too.

\section{References}

Baker DP, Day R, Salas E (2006) Teamwork as an essential component of high reliability organizations. Health Services Research 41(4): 1576-1598.

Beaubien JM, Baker DP (2004) The use of simulation for training teamwork skills in health care: how low can you go? Quality \& Safety in Health Care 13(1): i51-i56.

Brown J (2008) Applications of simulation technology in psychiatric mental health nursing education. Journal of Psychiatric and Mental Health Nursing 15(8):638-644.

Brown A (2015) Simulation in undergraduate mental health nursing education: a literature review. Clinical Simulation in Nursing 11(10): 445-449. 
Braude P, Reedy G, Dasgupta D, Dimmock V, Jaye P, Birns J (2015) Evaluation of a simulation training programme for geriatric medicine. Age Aging 44(4): 677-682.

Castells M (2000) The Rise of the Network Society, $2^{\text {nd }}$ ed. Oxford: Blackwell Publishing.

Cooper S, Cant R, Porter J, Bogossian F, McKenna L, Brady S, Fox-Young S (2012) Simulation based learning in midwifery education: a systematic review. Women and Birth 25(2): 64-78.

De Man A (2004) The Network Economy - Strategy, Structure and Management. Cheltenham: Edward Elgar Publishing Limited.

Drinka T, Clark P (2000) Health Care Teamwork. Interdisciplinary Practice and Teaching. USA: Greenwood Publishing Group.

Duff B (2013) Creating a culture of safety by coaching clinicians to competence. Nurse Education Today 33(10): 1108-1111.

Forneris SG, Neal DO, Tiffany J, Kuehn MB, Meyer HM, Blazovich LM, Holland AE, Smerillo M (2015) Enhancing clinical reasoning through simulation debriefing: a multisite study. Nursing Education Perspectives 36(5): 304-310.

Etelä-Pohjanmaan Sairaanhoitopiiri (South Ostrobothnia Hospital District) (2019). Retrieved from: https://bit.ly/2VRvA3K.

European Commission (2014) Directorate-General for Enterprise and Industry Evaluation of the SME Definition. Retrieved from: https://bit.ly/2Wcr1q8.

Grigg L, Johnston R, Milson N (2003) Emerging issues for cross-disciplinary research: conceptual and empirical dimensions. Canberra: Commonwealth of Australia.

Hansen J, Bratt M (2015) Competence acquisition using simulated learning experiences: a concept analysis. Nursing Education Perspectives 36(2): 102-107.

Holli K, Saloranta A (2016) Osaaminen tulevaisuuden sote-maailmassa. TUSO-hankkeen loppuraportti (Knowledge in the future world of social care. Final report of the TUSO project). Retrieved from: https://bit.ly/30P9EKH.

Holland LHM (2006) Expansion of cross-disciplinary science research defines Hyman's tenure. Retrieved from: http://www.thecrimson.com/article.aspx.

Hravnak M, Beach M, Tuite P (2007) Simulator technology as a tool for education in cardiac care. The Journal of Cardiovascular Nursing 22(1): 16-24.

ICN-International Council of Nurses (2012) The ICN code of ethics for nurses. Retrieved from: https://bit.ly/2FY6KcP.

Isoherranen K, Rekola L, Nurminen R (2008) Enemmän yhdessä - moniammatillinen yhteistyö (Together we are more - multiprofessinal collaboration). Helsinki: Sanoma Pro Oy.

Issenberg SB, Mcgaghic WC, Petrusa ER, Gordon DJ, Scalese RJ (2005) Features and uses of high-fidelity medical simulations that lead to effective learning: a BEME systematic review. Medical Teacher 27(1):10-28.

Jeffries PR (2015) Signs of maturity. Simulations are growing and getting more attention. Nursing Education Perspectives 36(6): 358-359.

Järviniemi P (2012) Muuttuvan työelämän tila ja tarpeet Suomessa. TEM raportteja 13/2012 (The state and needs of the changing working life in Finland. TEM report). Retrieved from: https://bit.ly/2HWvanR.

Karjalainen L, Räisänen R, Saranki-Rantakokko S (2016) Verkostomainen osaamisen kehittämisen toimintamalli tulevaisuuden Sotelle (Action model for the development of network-like competence for future social and health services) Series B. Report no. 17/2016. Rovaniemi: University of Applied Sciences.

Katajamäki E (2010) Moniammatillisuus ja sen oppiminen (Multiprofessionality and how to learn it). A case study at the University of Applied Sciences in the field of Social and Health Care. Academic dissertation, University of Tampere. 
Kuure T, Lidman J (Edn.) (2012) Yhteisellä työllä parempaa: Opaskirja monialaisen yhteistyön kehittämiseksi nuorten hyvinvointipalveluissa (Better results together: a guidebook for the development of multiprofessional collaboration in youth welfare services). Tampere: Sosiaalikehitys.

Linnamaa R, Sotarauta M (2000) Verkostojen utopia ja arki. Tutkimus EteläPohjanmaan kehittäjäverkostosta (The utopia and daily life of networks. A study on the developer network in South Ostrobothnia). University of Tampere, Regional Development Research Unit, SENTE Publications 7/2000.

March AL, Adams MH, Robinson C (2014) Student characteristics and perceptions of learning and confidence acquisition associated with simulation. Nursing Education Perspectives 35(5): 335-336.

McPherson K, Headrick L, Moss F (2001) Working and learning together: good quality care depends on it, but how can we achieve it? Quality in Health Care 10(2): ii46ii53.

Ministry of Education and Culture (2014) Kansallisen osaamisperustan vahvistaminen. Johtopäätöksiä (Strengthening the national competence foundation. Conclusions). Publications of the Ministry of Education and Culture no. 2014: 19.

Motola I, Devine LA, Soo Chung H, Sullivan JE, Issenberg SB (2013) Simulation in healthcare education: a best evidence practical guide. AMEE Guide no. 82. Medical Teacher 35(10): e1511-1530.

Mäkimattila M (2014) Organizing for systemic innovations: research on knowledge, interaction and organizational interdependencies. Lappeenranta: Lappeenranta University of Technology.

Murray C, Grant M, Howart M, Leigh J (2008) The use of simulation as a teaching and learning approach to support practice learning. Nurse Education in Practice 8(1): 5-8.

Provan K, Kenis P (2008) Modes of network governance: structure, management, and effectiveness. Journal of Public Administration Research and Theory 18(2): 229-252.

Research and Innovation Council (2014). Uudistava Suomi: tutkimus - ja innovaatiopolitiikan suunta 2015-2020 (Innovative Finland: directions for research and innovation 2015-2020). Retrieved from: https://bit.ly/2HFA6id

Rossetti J, Musker K, Smyth S, Byrne E, Maney C, Selig K, Jones-Bendel T (2014) Creating a simulated mental health ward. Lessons learned. Journal of Psychosocial Nursing and Mental Health Services 52(10): 52-58.

Salminen-Tuomaala M, Haapasalmi S, Jaskari P, Paussu P, Tupiini T, Uitto S (2019 forthcoming) Simulaatiovalmennukseen osallistuvien sosiaali - ja terveysalan pkyritysten henkilökunnan kokemukset osaamisestaan (Social and healthcare staff's experiences of simulation coaching in SMEs). Tutkiva Hoitotyö.

Salminen-Tuomaala M, Kangasluoma E, Kurunsaari M-T, Niinimäki A (2018) Social and healthcare staff's self-reported simulation learning needs in small and middle-sized enterprises. Clinical Nursing Studies 6(3): 1-10.

Salminen-Tuomaala M, Jaskari P, Perälä S, Rouvala C (2017) Nursing and medical staff's experiences of simulation education. Clinical Nursing Studies 5(4): 73-80.

Salminen-Tuomaala M, Jaskari P (2017) Nursing students' experiences of multiprofessional simulation education. Clinical Nursing Studies 6(2): 17-26.

Salminen-Tuomaala M (2015) Kansainvälisen tutkimus - ja kehittämishanketoiminnan edistäminen ammattikorkeakoulussa - sillanrakentamista ja brokerointiosaamista (Promotion of International Research and Development at a University of Applied Sciences - Building Bridges and Brokering Competence). Seinäjoki University of Applied Sciences.

SeAMK-About Us (2019) President's Greeting. Retrieved from https://ces.to/aP41kW.

Sedu (2019) Education and Training. Retrieved from: https://bit.ly/2MbtVGW. 
Ståhle P, Laento K (2000) Strateginen kumppanuus - avain uudistumiskykyyn ja ylivoimaan (Strategic Partnership - a Key to Innovations and Excellence). Porvoo: WSOY.

Valkokari K, Hyötyläinen R, Kulmala H, Malinen P, Möller K, Vesalainen J (2008) Verkostot liiketoiminnan kehittämisessä (Networks in the Development of Business Operations). Helsinki: WSOYpro.

Vesalainen J (2002) Kaupankäynnistä kumppanuuteen: yritysten välisten suhteiden elementit, analysointi ja kehittäminen (From business to partnership: elements, analysis and development in relations). Helsinki: Metalliteollisuuden Kustannus Oy.

Vuokila-Oikkonen P (2002) Akuutin psykiatrisen osastohoidon yhteistyöneuvottelun keskustelussa rakentuvat kertomukset (Narrative unfolding in cooperative team meetings in acute psychiatric care). Academic dissertation, University of Oulu. Retrieved from: https://bit.ly/30L1HpH. 
